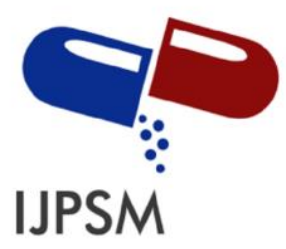

Ravindra Hiwse et al, International Journal of Pharmaceutical Sciences and Medicine (IJPSM),

Vol.7 Issue. 1, January- 2022, pg. 59-80

ISSN: 2519-9889

Impact Factor: 5.721

\title{
Formulation and Evaluation of Fast Dissolving Film of Imipramine Hcl
}

\author{
Ravindra Hiwse ${ }^{* 1}$; Rajat Pawar $^{1}$; Sunita Patidar ${ }^{1}$ \\ Swami Vivekanand College of Pharmacy, Indore, India \\ DOI: 10.47760/ijpsm.2022.v07i01.003
}

\begin{abstract}
This research work was aimed to provide faster onset of action of Imipramine Hcl (used for the treatment depression and bed wetting) by formulating its fast-dissolving film (FDF). Imipramine Hcl belongs to BCS I. The FDF of Imipramine Hcl was prepared by solvent casting method using HPMC (film forming agent), Glycerol (plasticizer), Citric acid (saliva stimulating agent), Mannitol (sweetening agent). The formulation was optimized by two factors, three levels $\left(3^{2}\right)$ was used for the formulation optimization of fast dissolving film of Imipramine $\mathrm{Hcl}$ and experimental trials are performed on all 9 formulations. In which the amount of HPMC, Glycerol was selected as independent variables (factor) varied at three different level: low (-1), medium (0), and high $(+1)$ levels. The drug release and disintegration time used as dependent variables (response). and formulation was evaluated for weight variation, thickness, folding endurance, drug content, in- vitro disintegration, in vitro dissolution study and stability study. Based on results it was concluded that FDF (F3) showed faster onset of action.
\end{abstract}

Keywords - FDFs, Imipramine Hcl, Polymers, FTIR, Bed- Wetting, HPMC.

\section{INTRODUCTION}

An oral film delivery is emerging as an advanced alternative to the traditional oral method of drug administration. The oral film is a solid dosage form of drug administration that dissolves when administered. The oral film doesn't need to be chewed or taken with water. Oral films contain active drugs that are designed for oral administration, allowing the drug to bypass the first-pass metabolism in the liver which leads to an increase in drug bioavailability.

Rapid or fast dissolving oral thin film is becoming an increasingly popular drug delivery system because of its wide and varied benefits. The oral film dissolves in few seconds when comes in contact with saliva, it doesn't need water to swallow thus, it is considered best for children and elderly patients. Mouth dissolving films contain amorphous polymers which aid in the rapid dissolution of the drugs. Above points lead to improvement in patient compliance 


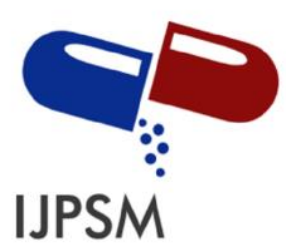

Ravindra Hiwse et al, International Journal of Pharmaceutical Sciences and Medicine (IJPSM), Vol.7 Issue. 1, January- 2022, pg. 59-80

ISSN: 2519-9889

Impact Factor: 5.721

and inspire pharmaceutical manufacture to invest their money in switching from the former products in markets to FDFs. ${ }^{1}$

The pharmaceutical dosages are administered in the form of pills, granules, powders, and liquids. Generally, a pill is supposed to be swallowed intact or chewed to deliver a precise dose of medication to the patient. The pills, tablets, and capsules have the quality to retain their shapes under moderate pressure. Some patients, especially geriatric and pediatric groups face difficulty in swallowing solid dosage forms and have the risk of choking. To comfort such patients, a variety of fast-dissolving drug delivery modes have been developed. Fast dissolving drug delivery systems are generally manufactured by a variety of technologies, which are direct compression, wet granulation and freeze drying. Some make use of different disintegrating mechanisms, such as high levels of disintegrating or effervescent agents, which cause the dosages to disintegrate rapidly in the mouth. The oral route of administration still continues to be widely used accepted route, contributing to 50 - $60 \%$ of total drug formulations because of ease of administration, self-medication, and pain avoidance as compared to parenteral mode. Most commonly elderly patients experience problems in swallowing solid dosage forms. Oral administration of conventional tablet poses problems, when a patient is mentally ill, developmentally disabled and in nausea. In some cases, motion sickness, sudden episodes of allergic attack or coughing and unavailability of water, poses problem in swallowing. To avoid such discomforts while having medication pharmaceutical technologists have developed several mouth dissolving drug delivery systems. Normally the films are soluble in water at room temperature and break up in $30 \mathrm{sec}$ and vanish in a minute. As faster the drug goes into the solution, quicker its absorption and onset of clinical effect occurs. By altering the condition and formulation factors, it is possible to slow down or speed up dissolving rate in the mouth just by altering the formulation factors and conditions. The mouth dissolving films-contain active ingredients, flavors, sweeteners and other ingredients, these materials are released as the film dissolves. ${ }^{2-3}$ 


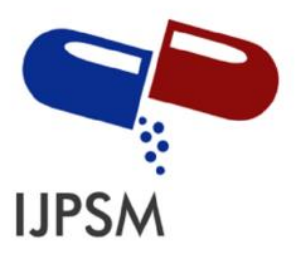

Ravindra Hiwse et al, International Journal of Pharmaceutical Sciences and Medicine (IJPSM), Vol.7 Issue. 1, January- 2022, pg. 59-80

ISSN: 2519-9889

Impact Factor: 5.721

\section{MATERIAL AND METHOD}

\section{Materials:}

Imipramine Hcl was obtained as Yarrow chem. Pvt. Ltd. HPMC, Glycerol, Mannitol, Citric acid was obtained from loba chemicals.

\section{Methods:}

\section{Preformulation.}

\section{Uv spectroscopy of Imipramine Hcl:}

weighed accurately $10 \mathrm{mg}$ quantity of Imipramine hydrochloride was dissolved in $100 \mathrm{ml}$ of methanol $(100 \mu \mathrm{g} / \mathrm{ml})$. $50 \mathrm{ml}$ was taken from the above stock solution and diluted with methanol to make it 100 . This will give the concentration of $50 \mu \mathrm{g} / \mathrm{ml}$. Further dilution is done with methanol to get standard concentrations of $5 \mu \mathrm{g}, 10 \mu \mathrm{g}, 15 \mu \mathrm{g}, 20 \mu \mathrm{g}$, and $25 \mu \mathrm{g} / \mathrm{ml}$. All the solution w/v were scanned in the range of $400 \mathrm{~nm}$ to $200 \mathrm{~nm}$. ${ }^{4}$

\section{Melting point:}

For determination of melting point of pure Imipramine Hcl Capillary tube method was used. In this method a small amount of Imipramine Hcl powder was taken in a closed end capillary tube and placed in melting point apparatus. The temperature was gradually increased and under close observation the temperature at which the powder completely melts was successfully detected. The temperature at which the powder melts is recorded as melting point of Imipramine Hcl.

\section{Preparation of Standard Curve of Imipramine Hcl:}

A standard curve prepared by dissolving 10mg of Imipramine $\mathrm{Hcl}$ in $100 \mathrm{ml}$ of methanol. From this $10 \mathrm{ml}$ diluted to $100 \mathrm{ml}$ using methanol to get standard concentration of $5 \mu \mathrm{g}$, $10 \mu \mathrm{g}, 15 \mu \mathrm{g}, 20 \mu \mathrm{g}$, and $25 \mu \mathrm{g} / \mathrm{ml}$. Absorbance was measured using UV-Visible spectrum at $255.0 \mathrm{~nm}$. 


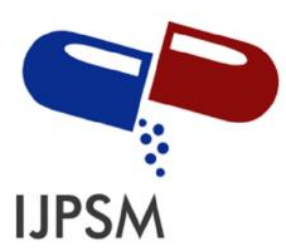

Ravindra Hiwse et al, International Journal of Pharmaceutical Sciences and Medicine (IJPSM), Vol.7 Issue. 1, January- 2022, pg. 59-80

ISSN: 2519-9889

Impact Factor: 5.721

\section{Preparation of buffers and reagents:}

Procedure of Imipramine hydrochloride for standard stock solution $(100 \mu \mathrm{g} / \mathrm{ml})$ in phosphate buffer (6.8) solution.

A standard stock solution of $100 \mu \mathrm{g} / \mathrm{ml}$ Imipramine $\mathrm{Hcl}$ was prepared by taking a $100 \mathrm{ml}$ of volumetric flask in which accurately weighed $10 \mathrm{mg}$ of Imipramine hydrochloride was dissolved in phosphate buffer solution ( $\mathrm{pH}$ 6.8) and the volume was made up to $100 \mathrm{ml}$.

From above stock solution, appropriate aliquots were pipetted into different volumetric flasks and volumes were made up to $10 \mathrm{ml}$ with phosphate buffer solution $(\mathrm{pH}-6.8)$ to get drug concentrations of $5 \mu \mathrm{g}, 10 \mu \mathrm{g}, 15 \mu \mathrm{g}, 20 \mu \mathrm{g}$ and $25 \mu \mathrm{g} / \mathrm{ml}$. The estimation of absorbance of these drug solutions were done at $\lambda \max -255.0 \mathrm{~nm}$. The calibration curve was validated by performing this procedure in triplicate ${ }^{\mathbf{4 - 5}}$

\section{Calibration curve of Imipramine Hcl solutions}

From the already prepared stock solution, appropriate aliquots were pipetted into different volumetric flasks and with phosphate buffer solution ( $\mathrm{pH}-6.8$ ) volume of up to $10 \mathrm{ml}$ is made to get drug concentrations of $5 \mu \mathrm{g}, 10 \mu \mathrm{g}, 15 \mu \mathrm{g}, 20 \mu \mathrm{g}$ and $25 \mu \mathrm{g} / \mathrm{ml}$. The absorbance of these drug solutions was estimated at $\lambda \max 255.0 \mathrm{~nm}$. This procedure was performed in triplicate to validate the calibration curve. ${ }^{6}$

\section{Determination of solubility of Imipramine $\mathrm{Hcl}$ in various medium:}

The solubility of Imipramine hydrochloride in various medium was determined by equilibrium_solubility method. In this method $5 \mathrm{ml}$ of each solvent were taken into a separate vial and excess amount of Imipramine hydrochloride was added in to vials containing distilled water and phosphate buffer ( $\mathrm{pH}$ 6.8). The vials were placed in magnetic stirrer at $37 \pm 20 \mathrm{C}$ for $12 \mathrm{hrs}$. The solutions were allowed to equilibrate for next $24 \mathrm{~h}$. The above solutions were transferred into Eppendorf tubes and got centrifuged for $5 \mathrm{~min}$. at $2000 \mathrm{rpm}$. The supernatants of each vial were filtered through a membrane filter of 0.45 microns, then appropriate dilutions were made and analysed by UV visible spectrophotometer at $255 \mathrm{~nm}$, the study was performed in triplicate. ${ }^{6}$ 


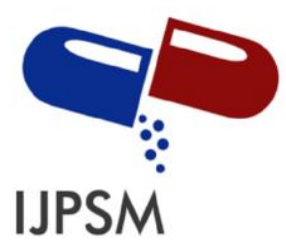

Ravindra Hiwse et al, International Journal of Pharmaceutical Sciences and Medicine (IJPSM),

Vol.7 Issue. 1, January- 2022, pg. 59-80

ISSN: 2519-9889

Impact Factor: 5.721

\section{Formulation of FDFs of Imipramine Hcl.}

Fast dissolving films were prepared by solvent casting method_as per the composition shown in table below .In this method, the required quantity of water soluble HPMC polymer was dissolved in distilled water in a beaker (covered with aluminium foil) with continuous stirring on magnetic stirrer to make required percentage of polymer solution and then the weighed quantity of ingredients like Imipramine $\mathrm{Hcl}$ as drug and, glycerol as plasticizer, citric acid as saliva stimulating agent, Mannitol as sweetener were dissolved in distilled water in another beaker and then this mixture was added to the polymer solution. This solution is stirred continuously for 2 hours and then left undisturbed for 12-16 hours to let all air bubbles escape. Then this polymeric- drug solution was poured on to the moulds, allowed to air dry and then packed in aluminium foil.

\section{Formulation Optimization of Fast Dissolving Film.}

\section{Table 6.1}

\begin{tabular}{|l|l|l|l|l|l|l|l|l|l|}
\hline Batch No. Ingredients & F1 & F2 & F3 & F4 & F5 & F6 & F7 & F8 & F9 \\
\hline Imipramine Hcl & 10 & 10 & 10 & 10 & 10 & 10 & 10 & 10 & 10 \\
\hline HPMC (mg) & 400 & 400 & 400 & 300 & 300 & 200 & 200 & 200 & 200 \\
\hline Glycerol (ml) & 0.05 & .01 & 0.075 & 0.05 & 0.1 & 0.075 & 0.05 & 0.1 & 0.075 \\
\hline Citric acid (mg) & 10 & 10 & 10 & 10 & 10 & 10 & 10 & 10 & 10 \\
\hline Mannitol (mg) & 10 & 10 & 101 & 10 & 10 & 10 & 10 & 10 & 10 \\
\hline Distilled water (ml) & 10 & 10 & 10 & 10 & 10 & 10 & 10 & 10 & 10 \\
& & & & & & & & & \\
\hline
\end{tabular}




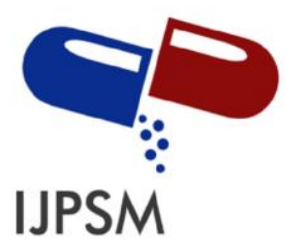

Ravindra Hiwse et al, International Journal of Pharmaceutical Sciences and Medicine (IJPSM), Vol.7 Issue. 1, January- 2022, pg. 59-80

ISSN: 2519-9889

Impact Factor: 5.721

\section{Evaluation of the Films}

\section{Visual inspection:}

The prepared oral films (with and without Imipramine) were evaluated for surface texture, peel-ability, transparency, homogeneity, and flexibility. ${ }^{3}$

\section{Weight of films:}

Total of 9 films were weighed on analytical balance and average weight was determined for each film. It is the required that all the films should have nearly constant weight. It ensures that a film contains the proper number of excipients and API. ${ }^{6}$

Film thickness: Digital Vernier caliper was used to measure the thickness of the films (with and without drug). The films with air bubbles and tears were considered defective and excluded from the analysis. Thickness was measured at five locations (four corners and center) then mean thickness was calculated. ${ }^{7}$

\section{Folding Endurance:}

All the films were tested manually for folding endurance by folding and unfolding the film at the same place. The number of times the film was folded and unfolded without breaking it, was recorded as folding endurance. ${ }^{\mathbf{8}}$

\section{Drug Content Uniformity:}

Imipramine $\mathrm{Hcl}$ was determined by dissolving the prepared fast dissolving film (FDF) of Imipramine $\mathrm{Hcl}$ in $100 \mathrm{ml}$ of phosphate buffer $(\mathrm{pH} \mathrm{6.8).} \mathrm{From} \mathrm{this,} \mathrm{the} \mathrm{aliquot} \mathrm{of} 1 \mathrm{ml}$ was taken and diluted to $10 \mathrm{ml}$ with distilled water. Then solution was filtered with Whatman filter paper and the solution was analysed on UV spectrophotometer at desired wavelength to calculate the amount of drug present in the film.

\section{In vitro Disintegration time of the films:}

To determine the disintegration time of the films (with and without Imipramine) Modified disintegration method was used. For that, $5 \mathrm{ml}$ of water was taken in a Petri dish, then the film was placed in centre of the Petri dish. The time taken by the film to start disintegrating or break was recorded as disintegration time. ${ }^{8}$ 


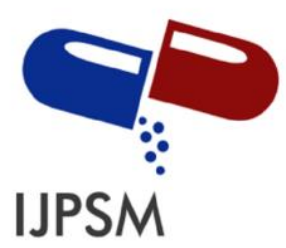

Ravindra Hiwse et al, International Journal of Pharmaceutical Sciences and Medicine (IJPSM), Vol.7 Issue. 1, January- 2022, pg. 59-80

ISSN: 2519-9889

Impact Factor: 5.721

\section{In- vitro Dissolution test:}

The dissolution study of the MDF was determined in Electro lab Dissolution Apparatus type II following USP Paddle method. All tests were conducted in $250 \mathrm{ml}$ of Phosphate buffer $\mathrm{pH}$ 6.8. The dissolution medium was maintained at $37 \pm 0.5^{\circ} \mathrm{C}$ and the paddle rotation speed was $50 \mathrm{rpm}$. Aliquot of $5 \mathrm{ml}$ was withdrawn at specific intervals and were immediately filtered through Whatman filter paper and analysed by spectrophotometry. The absorbance values were transformed to concentration by reference to a standard calibration curve obtained experimentally measured on UV spectrophotometer. ${ }^{9}$

\section{Fourier Transform Infrared (FTIR)}

The FTIR spectra of pure Imipramine Hcl powder were compared with the spectra of the fastdissolving oral films containing drug to see if there is any change in drug or any interaction between the drug and any of excipients in the formulation. ${ }^{\mathbf{1 0}}$

\section{RESULT AND DISCUSSION Identification of drug:}

The UV spectrum of Imipramine Hcl shows prominent absorbance maxima at wavelength $255 \mathrm{~nm}$ (fig No. 7.1) which is similar to the standard peaks therefore confirmed the identity of sample drug as Imipramine Hcl.

Reported absorbance maxima were Imipramine $\mathrm{Hcl}$ were $\lambda$ max at $255 \mathrm{~nm}$.

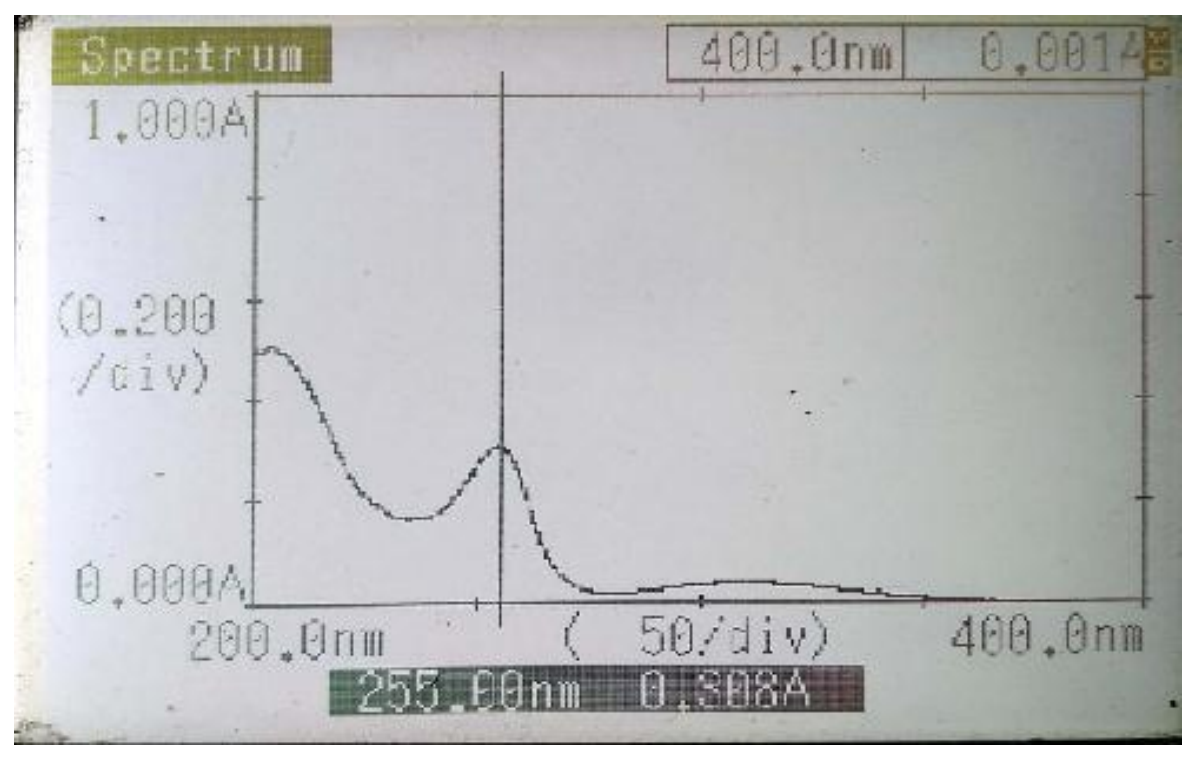

Figure 7.1 UV Spectrum of Imipramine Hcl 


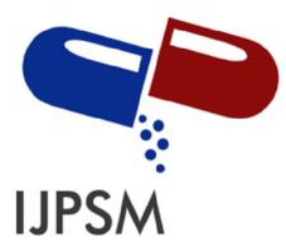

Ravindra Hiwse et al, International Journal of Pharmaceutical Sciences and Medicine (IJPSM), Vol.7 Issue. 1, January- 2022, pg. 59-80

ISSN: 2519-9889

Impact Factor: 5.721

\section{Melting point determination.}

Determination of Melting Point - measured melting point of pure Imipramine $\mathrm{Hcl}$ was found to be $174^{\circ} \mathrm{C}$.

Preparation Of Calibration Curves: The calibration curves of Imipramine $\mathrm{Hcl}$ in various solvents e.g., Distilled water, phosphate $(6.8 \mathrm{pH})$ was prepared.

Absorbance Data of Imipramine Hcl In Distilled Water For Preparation Of Calibration Curve, At 255nm.

Table 7.1

\begin{tabular}{|c|c|c|}
\hline S. NO. & Concentration $(\mu \mathrm{g} / \mathrm{ml})$ & Absorbance \\
\hline 1. & 5 & 0.331 \\
\hline 2. & 10 & 0.457 \\
\hline 3. & 15 & 0.762 \\
\hline 4. & 20 & 1.055 \\
\hline 5. & 25 & 1.247 \\
\hline
\end{tabular}

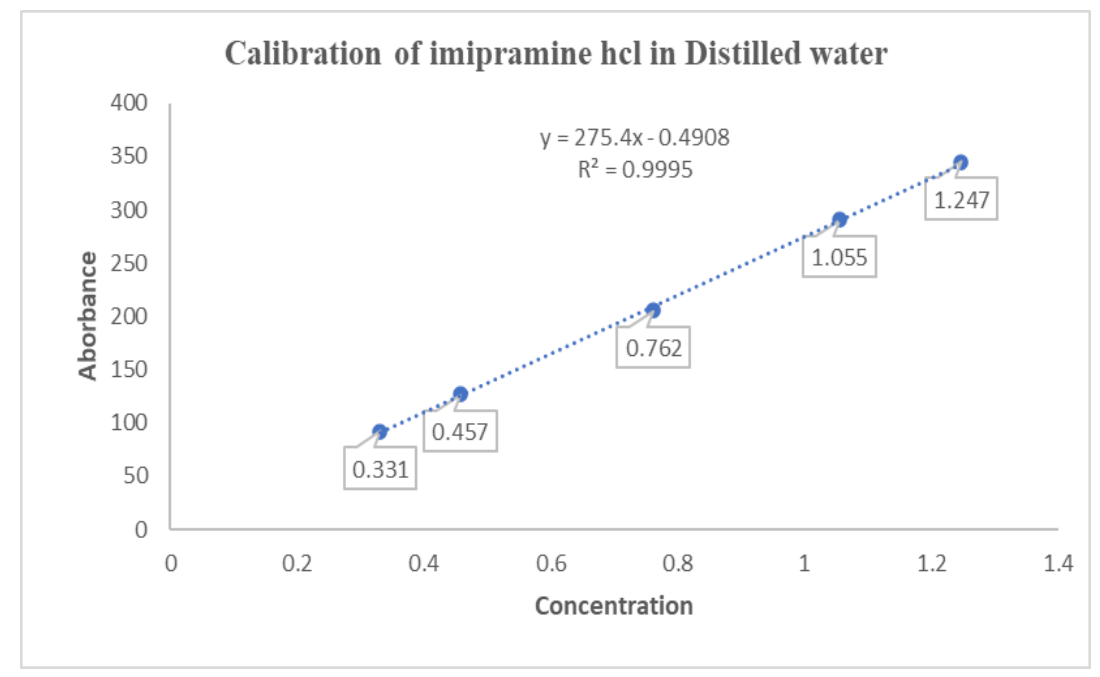

Figure 7.2 Calibration curve of Imipramine $\mathrm{Hcl}$ in distilled water $255.0 \mathrm{~nm}$. 


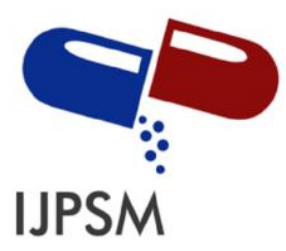

Ravindra Hiwse et al, International Journal of Pharmaceutical Sciences and Medicine (IJPSM), Vol.7 Issue. 1, January- 2022, pg. 59-80

Absorbance data of Imipramine $\mathrm{Hcl}$ in phosphate buffer $\mathrm{pH} 6.8$ for preparation of calibration curve, at $255 \mathrm{~nm}$.

Table 7.2

\begin{tabular}{|c|c|c|}
\hline S.NO. & Concentration $(\mu \mathrm{g} / \mathrm{ml})$ & Absorption \\
\hline 1. & 5 & 0.035 \\
\hline 2. & 10 & 0.043 \\
\hline 3. & 15 & 0.350 \\
\hline 4. & 20 & 0.744 \\
\hline 5. & 25 & 1.086 \\
\hline
\end{tabular}

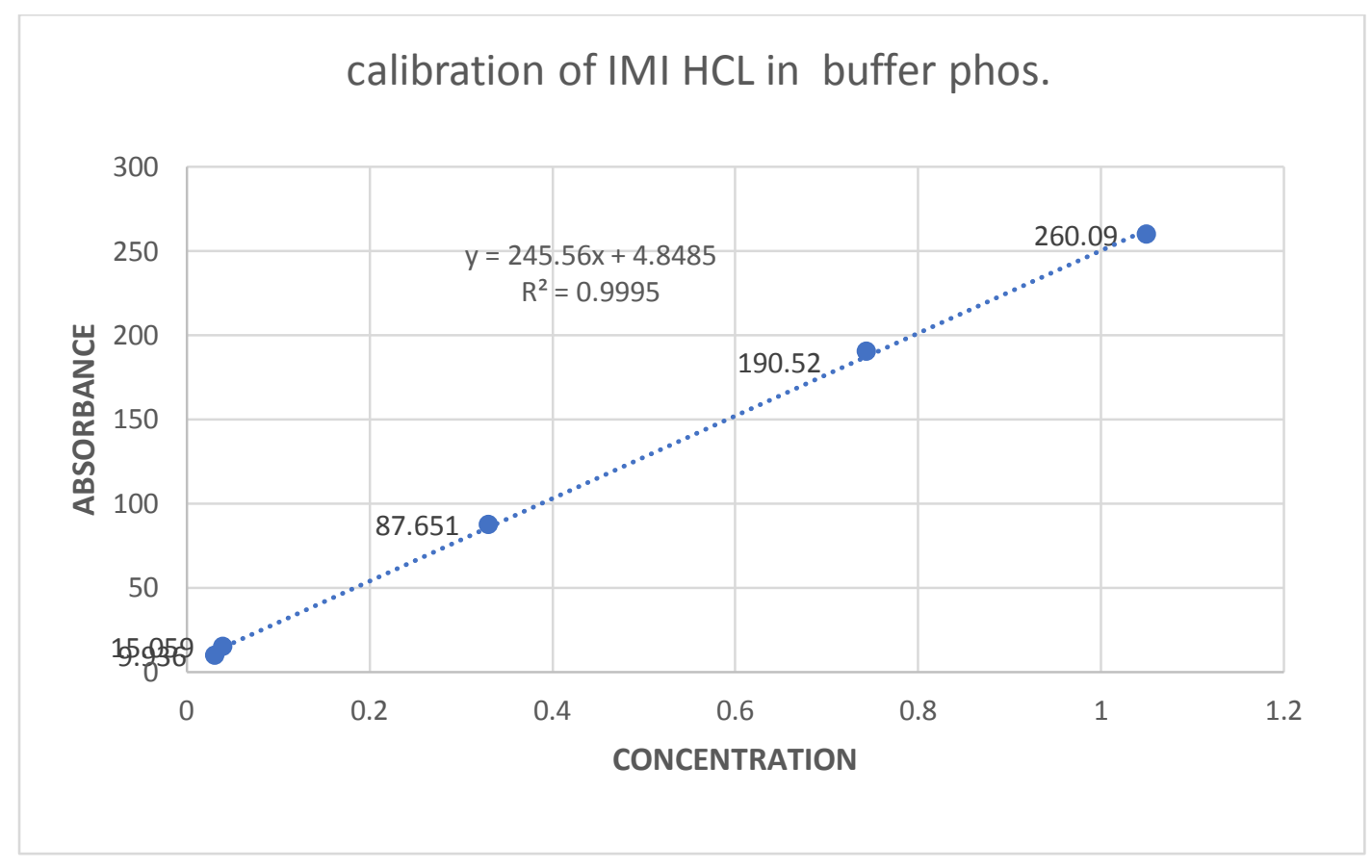

Figure 7.2 Calibration curve of Imipramine Hcl in phosphate buffer (pH 6.8) 255.0nm. 


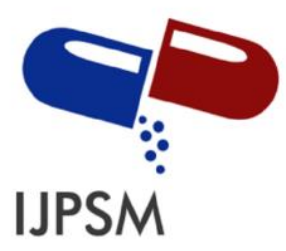

Ravindra Hiwse et al, International Journal of Pharmaceutical Sciences and Medicine (IJPSM), Vol.7 Issue. 1, January- 2022, pg. 59-80

\section{Determination of solubility of Imipramine $\mathrm{Hcl}$ in various medium:}

The solubility of Imipramine $\mathrm{Hcl}$ in various medium was studied and the results of study are shown in table below

Solubility data of Imipramine Hcl different medium studied.

Table 7.3

\begin{tabular}{|c|c|c|}
\hline S.NO & Solvent & Solubility $(\mathrm{mg} / \mathrm{ml})$ \\
\hline 1. & Distilled water & $0.75 \mathrm{mg} / \mathrm{ml}$ \\
\hline 2. & Phosphate Buffer 6.8 & $0.5 \mathrm{mg} / \mathrm{ml}$ \\
\hline
\end{tabular}

\section{Drug-Excipient Compatibility Studies by FT-IR}

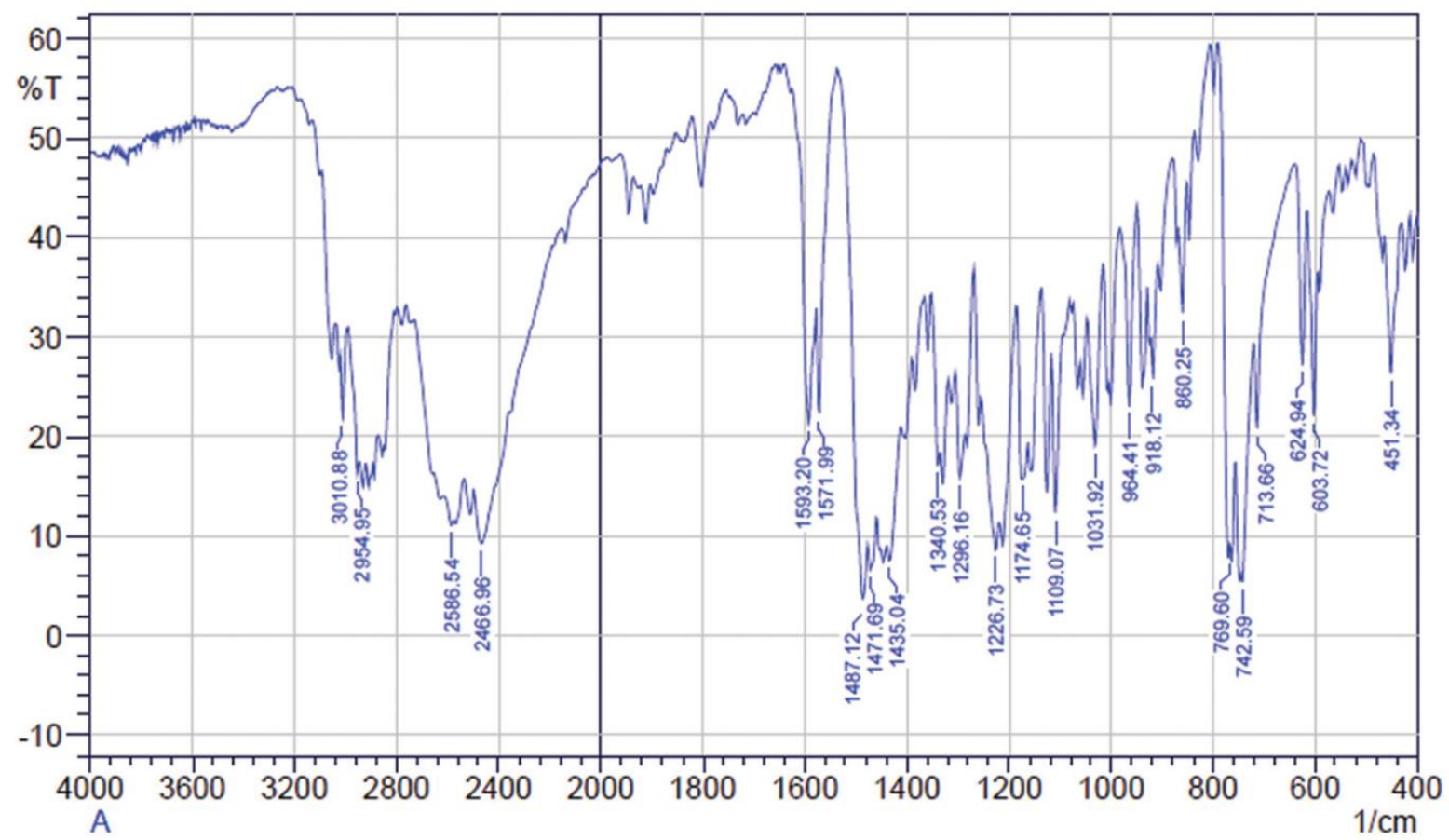




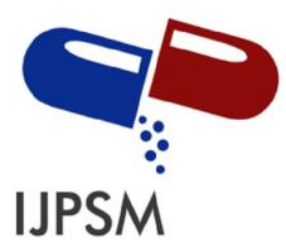

Ravindra Hiwse et al, International Journal of Pharmaceutical Sciences and Medicine (IJPSM), Vol.7 Issue. 1, January- 2022, pg. 59-80

ISSN: 2519-9889

Impact Factor: 5.721
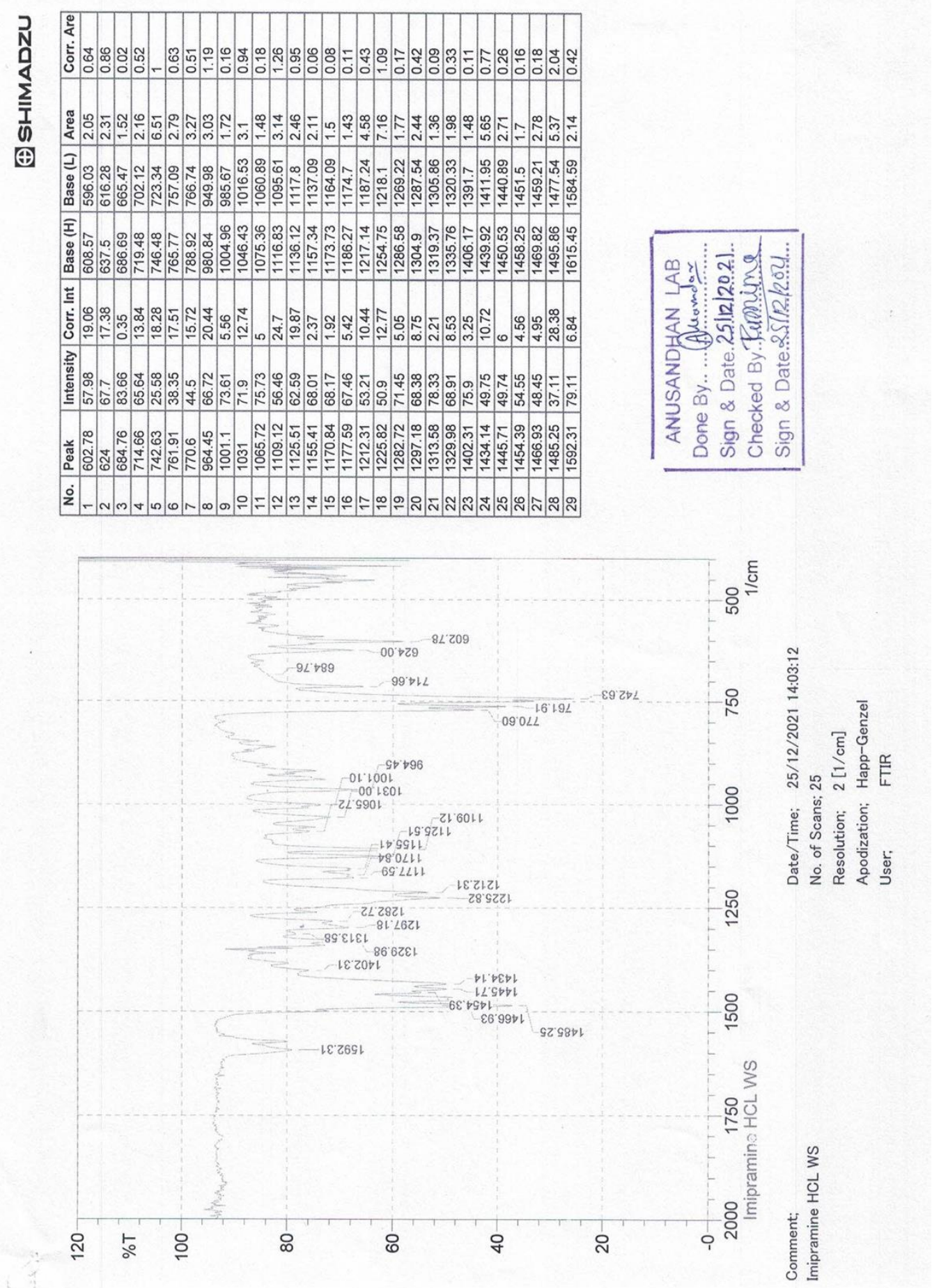

FIGURE 7.4 IR SPECTRA OF IMIPRAMINE HCL WITH HPMC. 


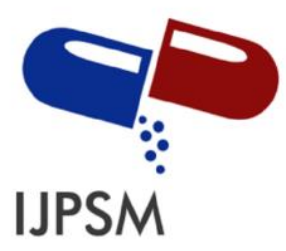

Ravindra Hiwse et al, International Journal of Pharmaceutical Sciences and Medicine (IJPSM), Vol.7 Issue. 1, January- 2022, pg. 59-80

ISSN: 2519-9889

Impact Factor: 5.721
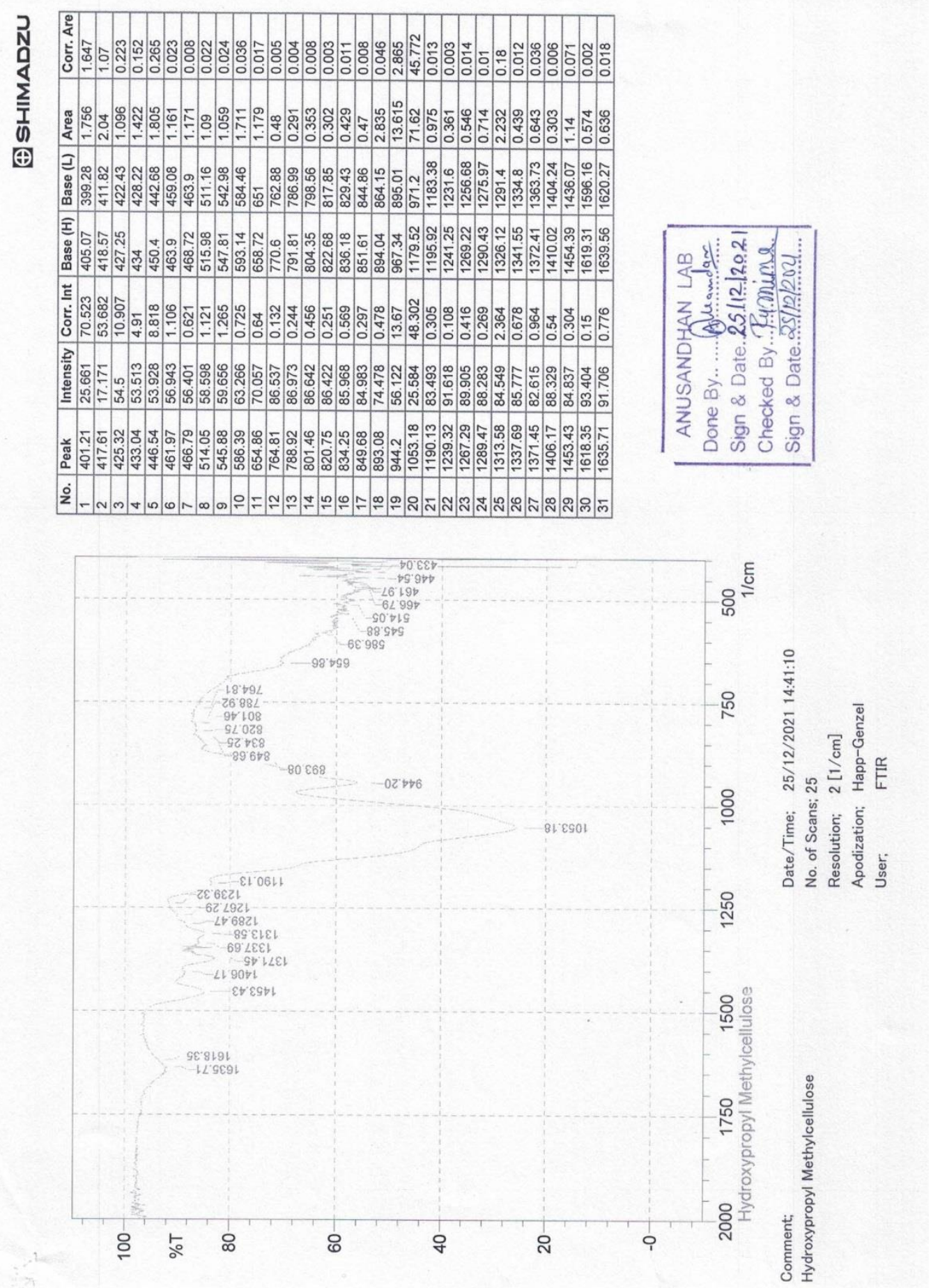

FIGURE 7.5 IR SPECTRA OF IMIPRAMINE HCL WITH HPMC. 


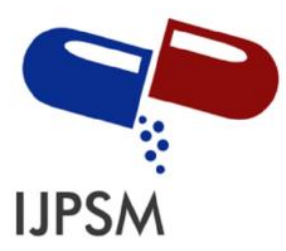

Ravindra Hiwse et al, International Journal of Pharmaceutical Sciences and Medicine (IJPSM), Vol.7 Issue. 1, January- 2022, pg. 59-80

ISSN: 2519-9889

Impact Factor: 5.721

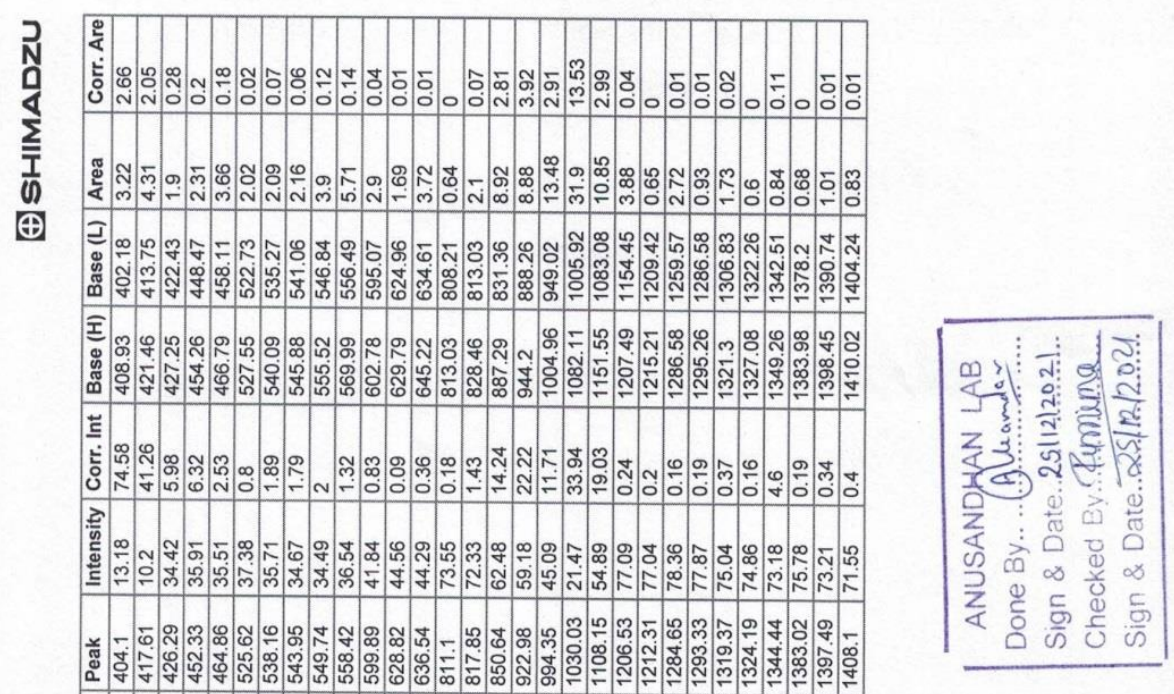

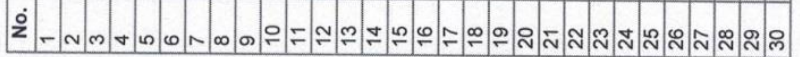

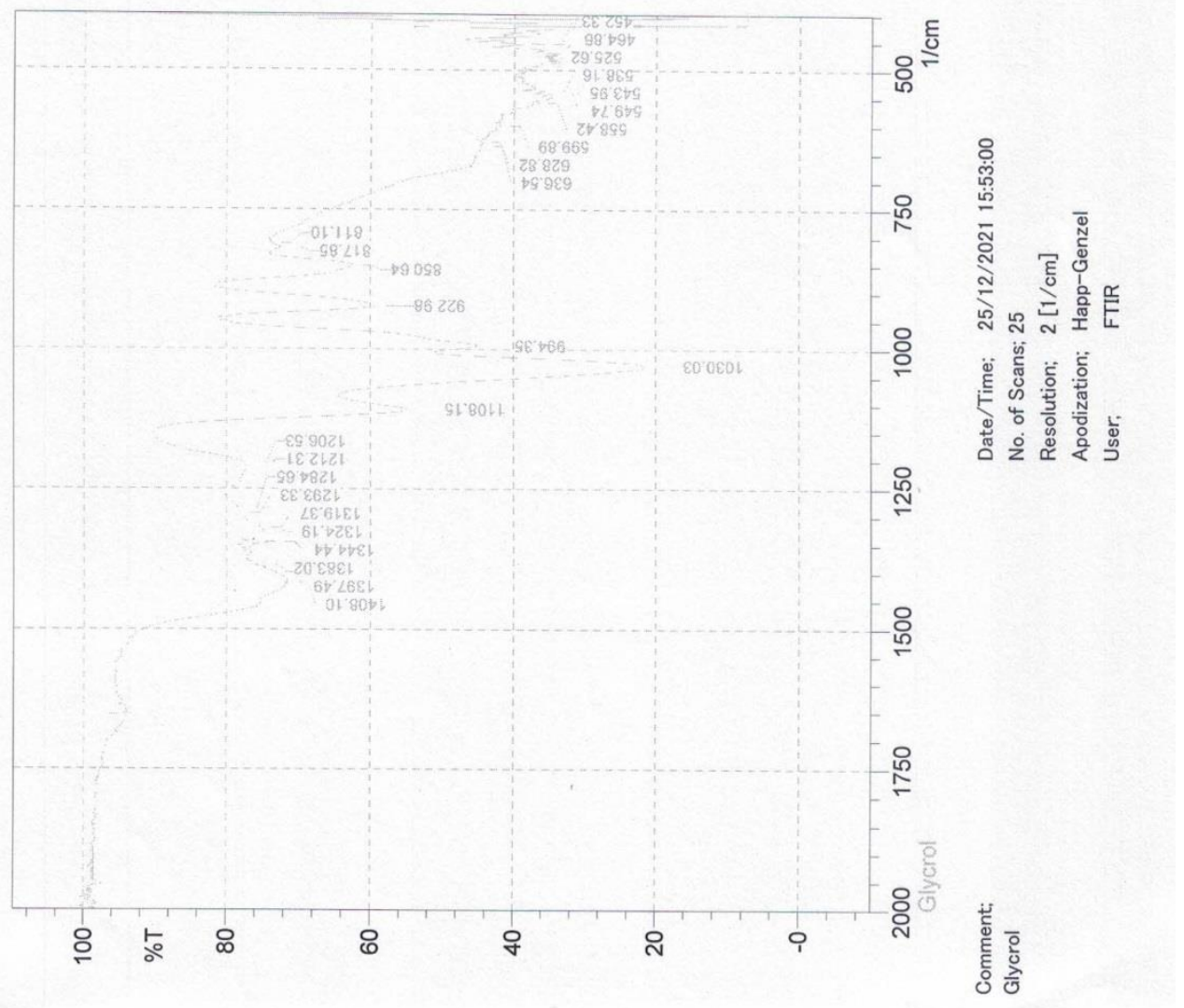

FIGURE 7.6 IR SPECTRA OF IMIPRAMINE HCL WITH GLYCEROL. 


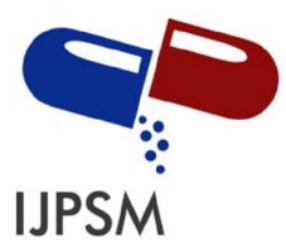

Ravindra Hiwse et al, International Journal of Pharmaceutical Sciences and Medicine (IJPSM), Vol.7 Issue. 1, January- 2022, pg. 59-80

ISSN: 2519-9889

Impact Factor: 5.721

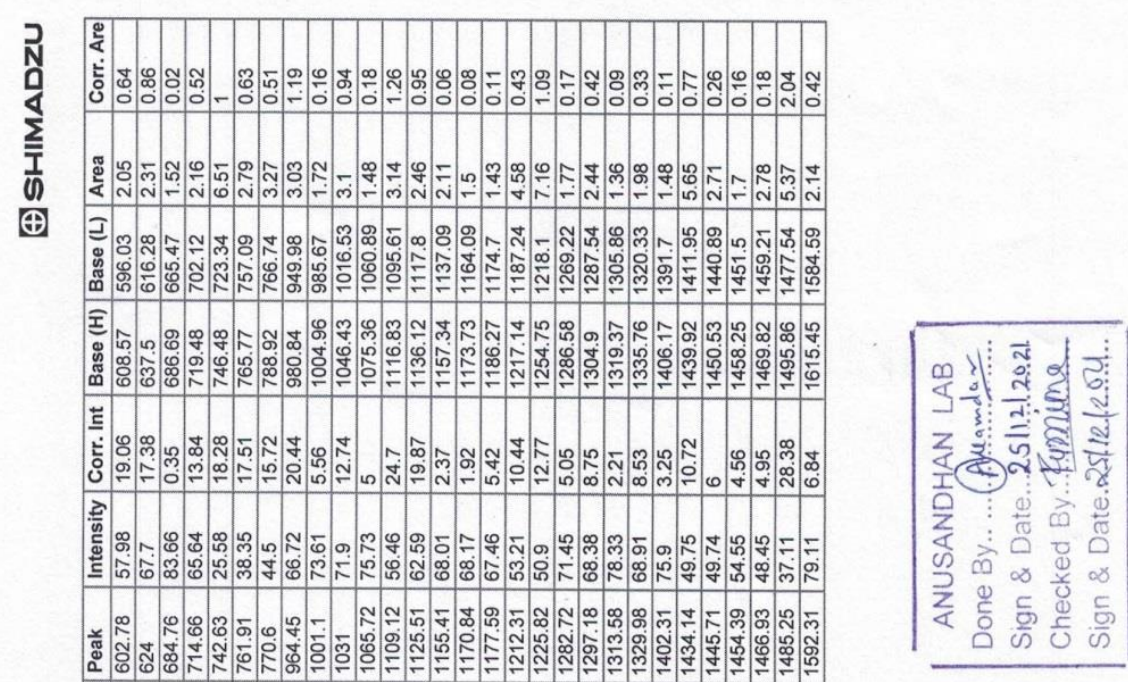

$\dot{s}-n m+m . n m \infty$ m

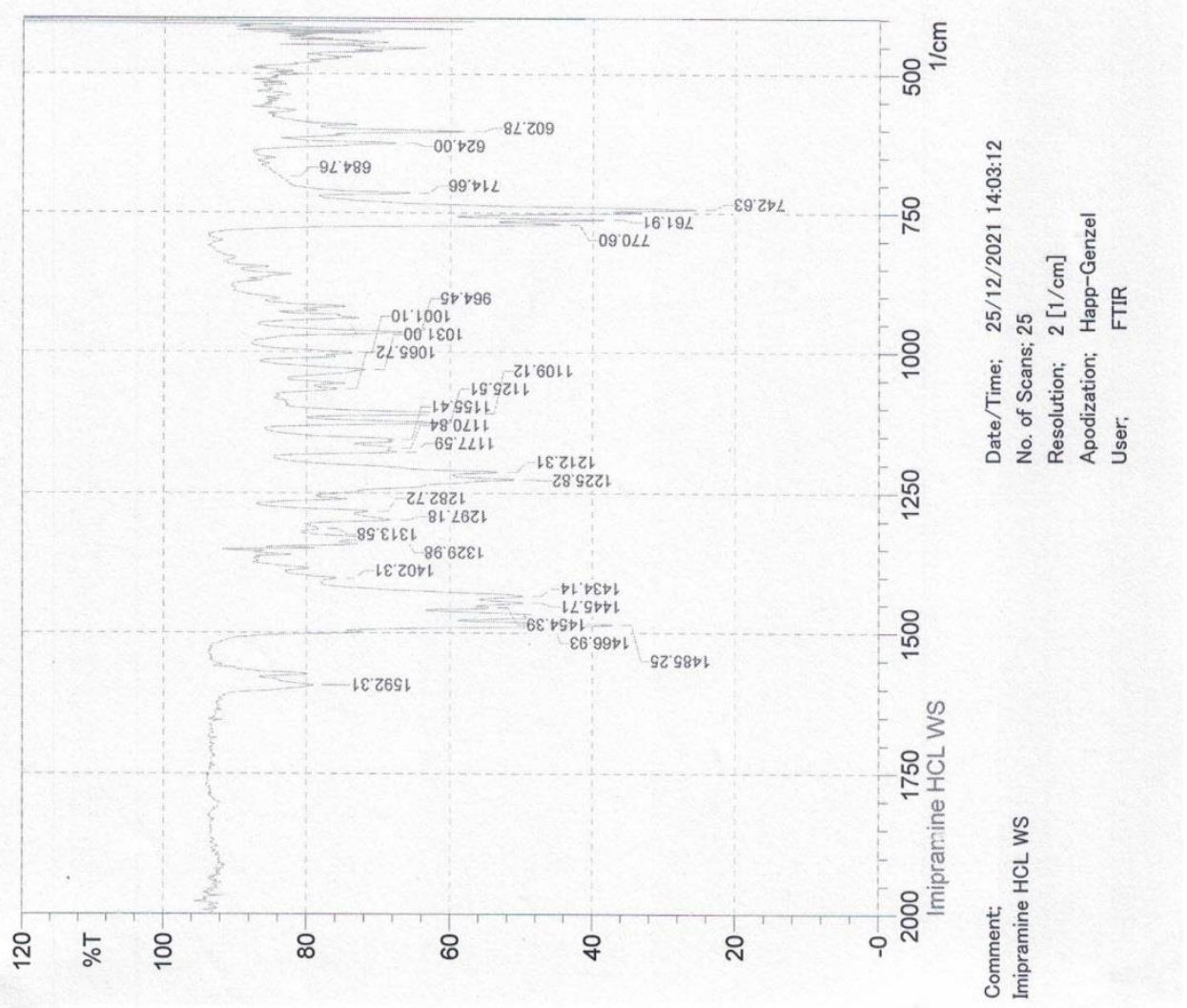

FIGURE 7.7 IR SPECTRA OF IMIPRAMINE HCL WITH GLYCEROL. 


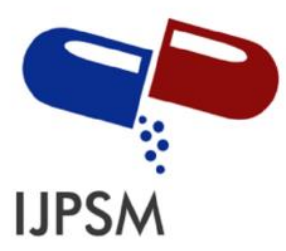

Ravindra Hiwse et al, International Journal of Pharmaceutical Sciences and Medicine (IJPSM), Vol.7 Issue. 1, January- 2022, pg. 59-80

ISSN: 2519-9889

Impact Factor: 5.721
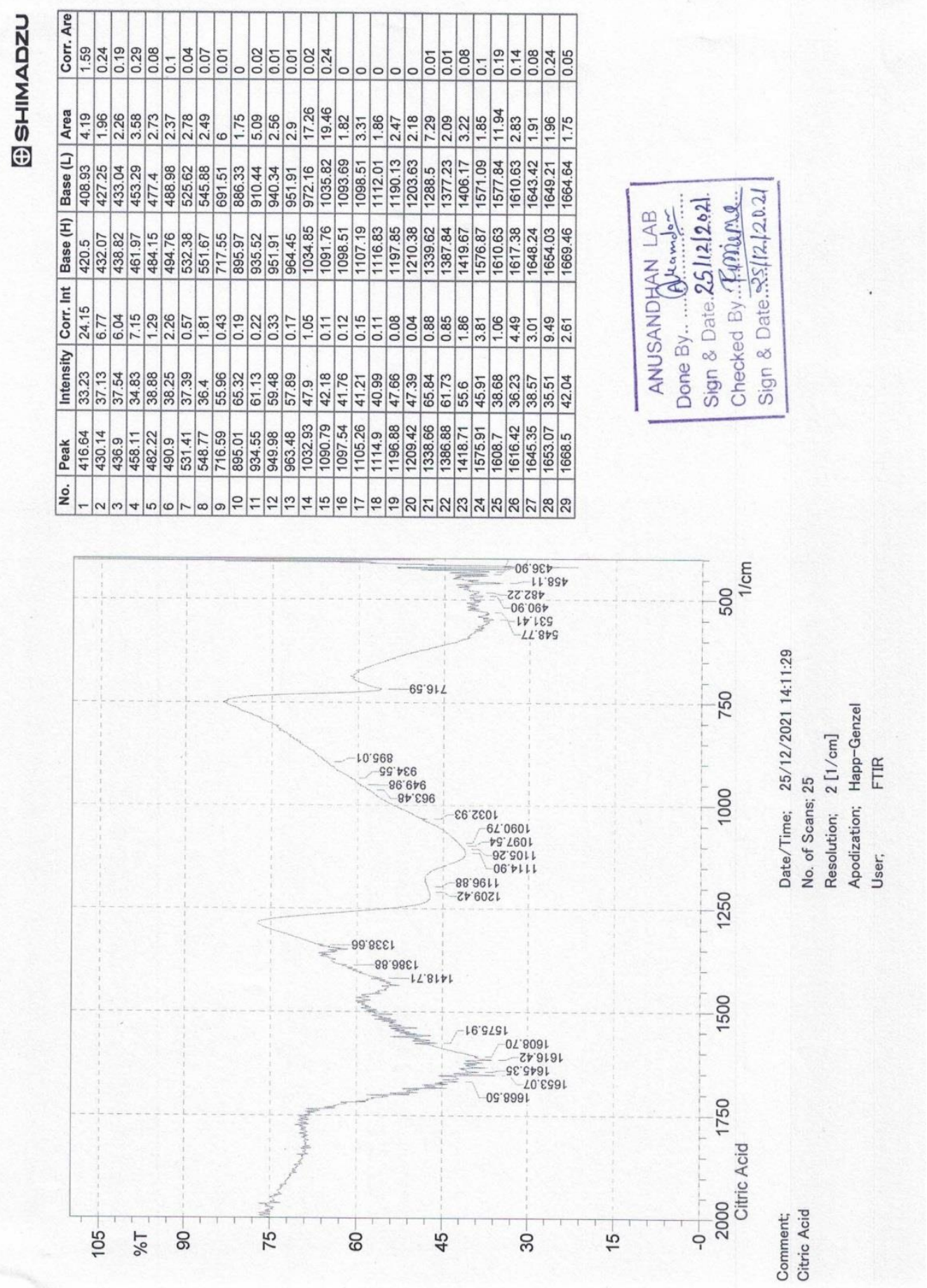

FIGURE7.8 IR SPECTRA OF IMIPRAMINE HCL WITH CITRIC ACID. 


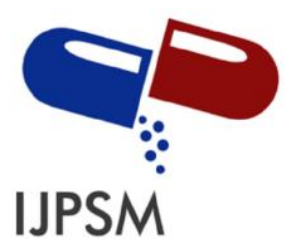

Ravindra Hiwse et al, International Journal of Pharmaceutical Sciences and Medicine (IJPSM), Vol.7 Issue. 1, January- 2022, pg. 59-80

ISSN: 2519-9889

Impact Factor: 5.721
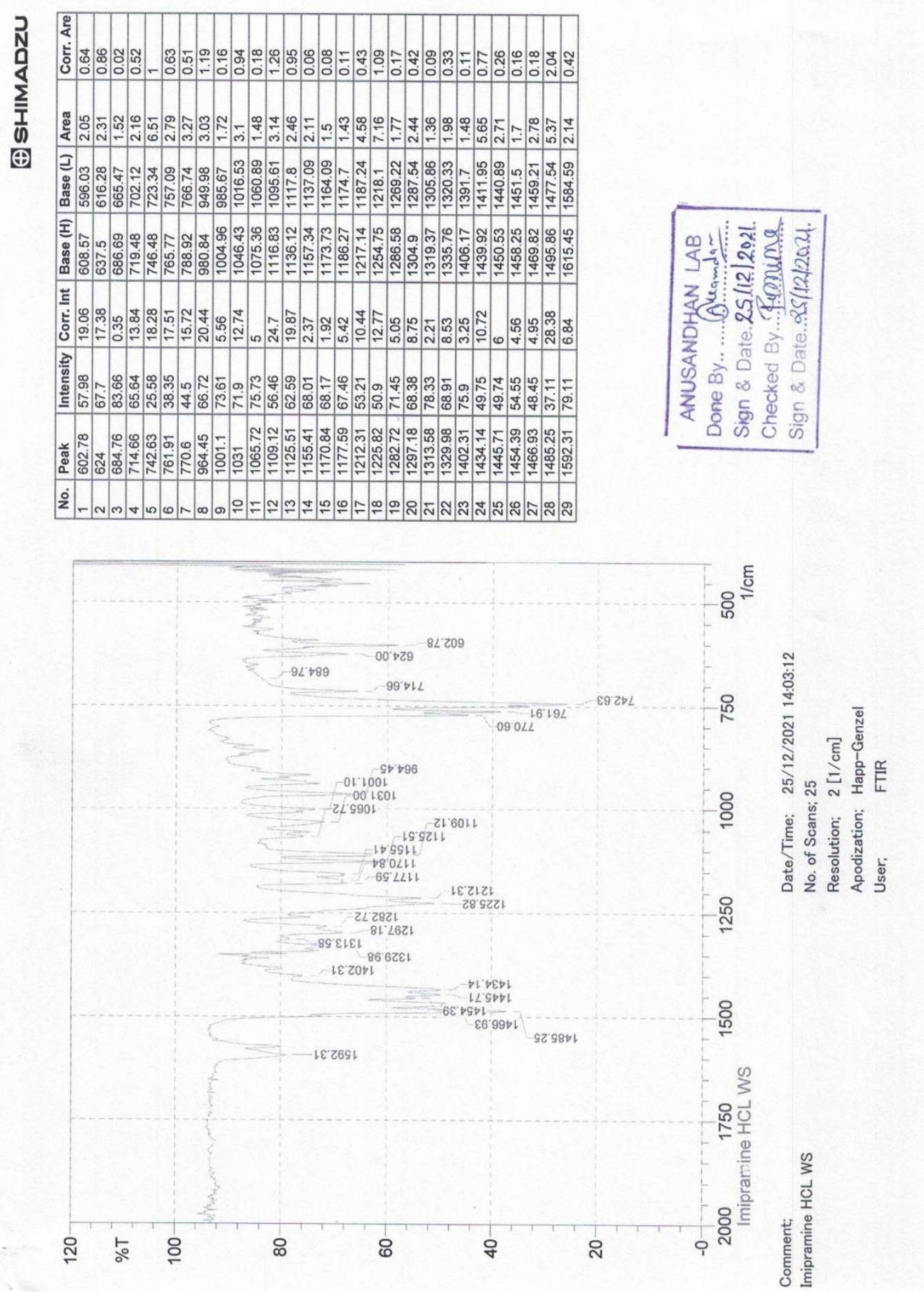

FIGURE 7.9 IR SPECTRA OF IMIPRAMINE HCL WITH CITRIC ACID. 


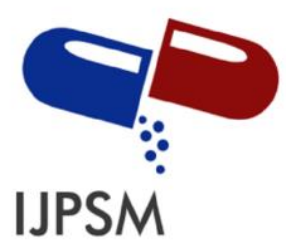

Ravindra Hiwse et al, International Journal of Pharmaceutical Sciences and Medicine (IJPSM), Vol.7 Issue. 1, January- 2022, pg. 59-80

ISSN: 2519-9889

Impact Factor: 5.721
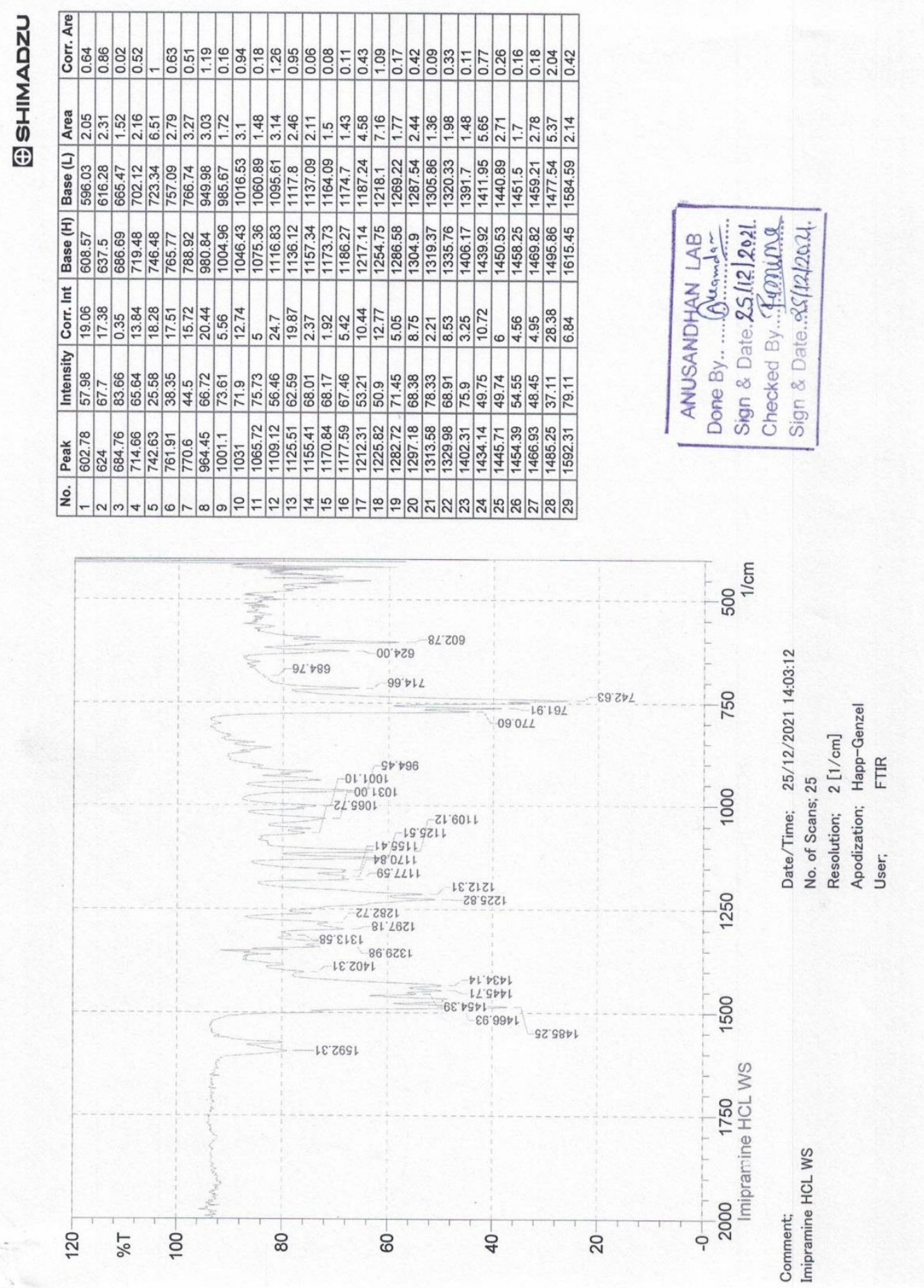

FIGURE 7.10 IR SPECTRA OF IMIPRAMINE HCL WITH MENNITOL. 


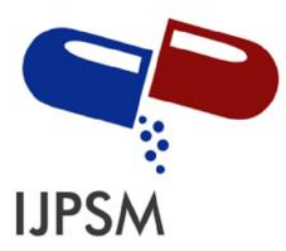

Ravindra Hiwse et al, International Journal of Pharmaceutical Sciences and Medicine (IJPSM), Vol.7 Issue. 1, January- 2022, pg. 59-80

ISSN: 2519-9889

Impact Factor: 5.721
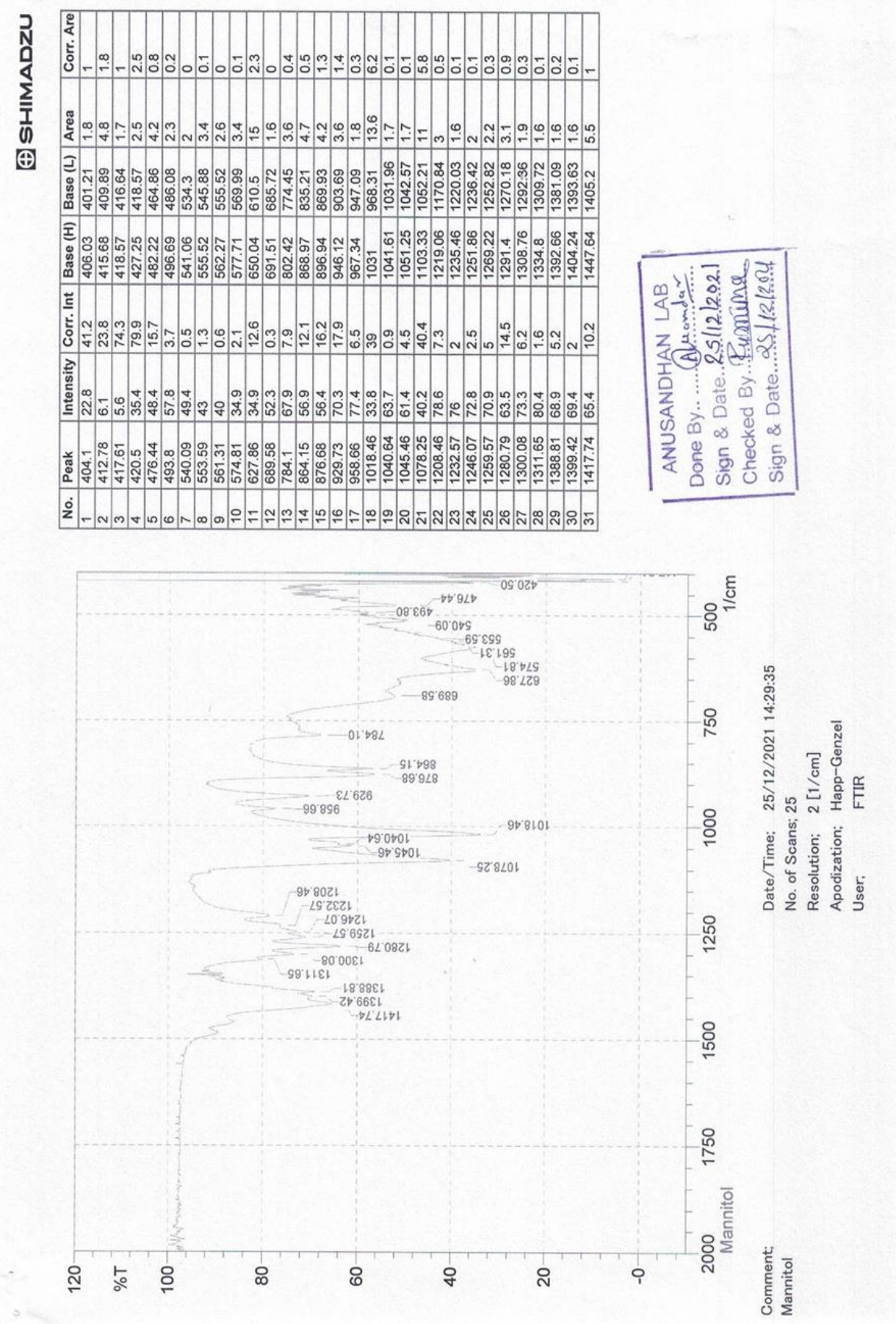

FIGURE 7.11 IR SPECTRA OF IMIPRAMINE HCL WITH 


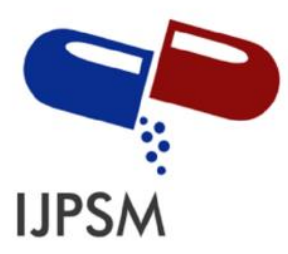

Ravindra Hiwse et al, International Journal of Pharmaceutical Sciences and Medicine (IJPSM), Vol.7 Issue. 1, January- 2022, pg. 59-80

EVALUATION DATA OF FAST DISSOLVING FILM OF IMIPRAMINE HCL

Table 7.4

\begin{tabular}{|l|l|l|l|l|l|}
\hline Formulation & $\begin{array}{l}\text { Weight } \\
\text { variation } \\
(\mathbf{m g}) \\
\text { Mean } \pm \text { SD }\end{array}$ & $\begin{array}{l}\text { Thickness } \\
(\mathbf{m m}) \\
\text { Mean } \\
\text { SD }\end{array}$ & $\begin{array}{l}\text { Folding } \\
\text { endurance } \\
\text { (Times) }\end{array}$ & $\begin{array}{l}\text { Drug } \\
\text { Content } \\
(\%)\end{array}$ & $\begin{array}{l}\text { Disintegration } \\
\text { Time } \\
(\mathbf{s e c}) \\
\text { Mean } \pm \text { SD }\end{array}$ \\
\hline F1 & $30.1 \pm 0.02$ & $0.01 \pm 0.07$ & 100 & 85.1 & 30 \\
\hline F2 & $34.5 \pm 0.05$ & $0.05 \pm 0.04$ & 85 & 86.6 & 28 \\
\hline F3 & $28.8 \pm 0.04$ & $0.09 \pm 0.02$ & 98 & 97.4 & 22 \\
\hline F4 & $31.0 \pm 0.06$ & $0.06 \pm 0.08$ & 99 & 86.6 & 20 \\
\hline F5 & $32.2 \pm 0.04$ & $0.04 \pm 0.4$ & 90 & 93 & 31 \\
\hline F6 & $27.01 \pm 0.09$ & $0.02 \pm 0.09$ & 92 & 92.2 & 34 \\
\hline F7 & $29 \pm 0.08$ & $0.1 \pm 0.06$ & 95 & 92.3 & 31 \\
\hline F8 & $28.8 \pm 0.05$ & $0.08 \pm 0.07$ & 97 & 87.7 & 26 \\
\hline F9 & $31 \pm 0.07$ & $0.07 \pm 0.05$ & 102 & 86.4 & 29 \\
\hline
\end{tabular}

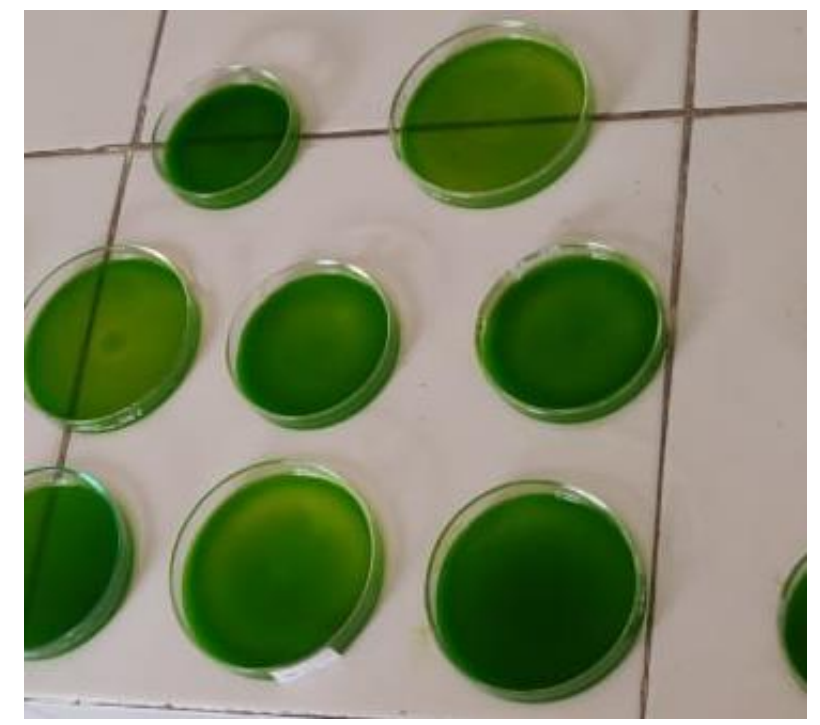

Imipramine Hcl loaded oral fast dissolving film in petridish. 


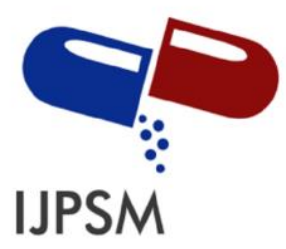

Ravindra Hiwse et al, International Journal of Pharmaceutical Sciences and Medicine (IJPSM), Vol.7 Issue. 1, January- 2022, pg. 59-80

ISSN: 2519-9889

Impact Factor: 5.721

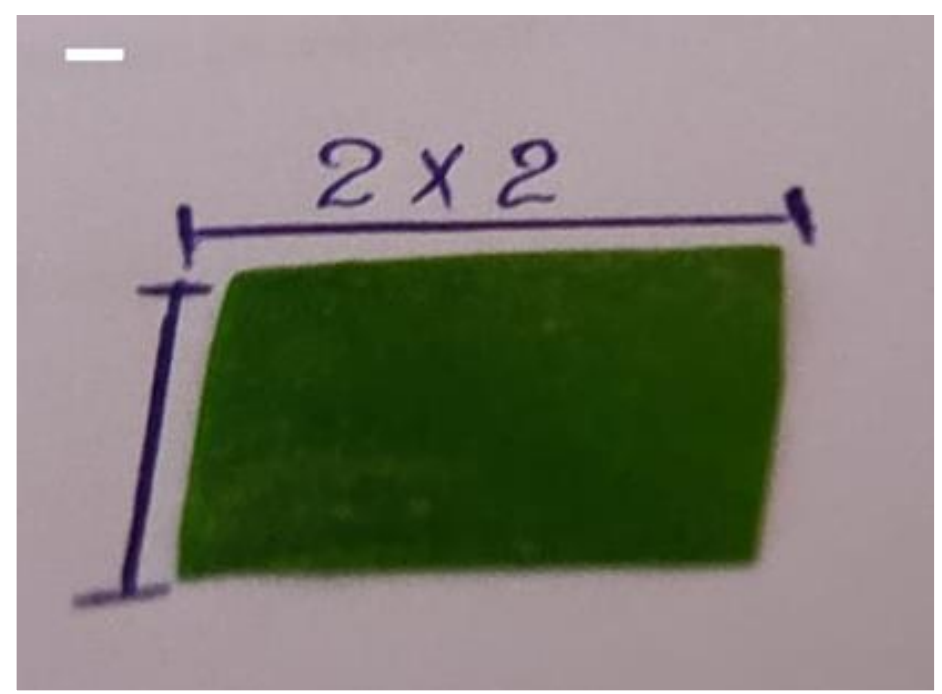

\section{Imipramine Hcl loaded oral fast dissolving film in cutted $2 \times 2$.}

\section{CONCLUSION}

$>$ Fast dissolving films are the most appreciated innovation done in recent times. These have countless benefits for large population.

$>$ They are most commonly used for pharmaceutical and nutraceuticals products.

$>$ "The fast-dissolving films", these prepared using hydrophilic polymers that dissolve (within $30 \mathrm{sec}$ ) on the tongue or buccal cavity mucosa, delivering the drug to the systemic circulation via buccal mucosa.

$>$ The fast-dissolving drug delivery systems are specially designed for the drugs which have low dose and extensive first pass metabolism, for desired increase in bioavailability.

$>$ Fast dissolving films are safe and favorable for children elderly and mentally ill patient who generally face problems while swallowing tablets and capsules.

$>$ Fast dissolving films contain amorphous polymers which aid in the rapid dissolution of the drugs. There is no need of water and chewing.

$>$ Above points lead to improvement in patient compliance and inspire pharmaceutical manufacture to invest their money in switching from the former products in markets to FDFs.

$>$ Among the final batch of 9 films and F3 were the perfect formulations which gave the expected results for standard parameters for evaluation of films. 


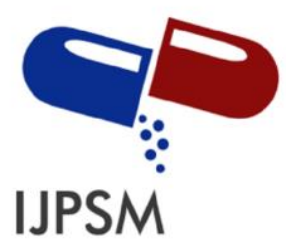

Ravindra Hiwse et al, International Journal of Pharmaceutical Sciences and Medicine (IJPSM), Vol.7 Issue. 1, January- 2022, pg. 59-80

ISSN: 2519-9889

Impact Factor: 5.721

\section{REFERENCES}

[1]. Bala R, Pawer P, Khanna S, orally dissolving strip: A new approach to oral drug delivery system. Int J Pharma, 2013: 3(2): 67- 76.

[2]. Bala R, Sharma S, A novel approach on fast dissolving film. Bfopcu ,2018:4(2)159-168.

[3]. Patil SL, Mahaparale PL, Tiwari S, Pavour KV, Sane PN. Fast dissolving oral films: an innovative drug delivery system.Int JRes Rev PharmApplSci2012;2:482-96.

[4]. Swati hardainiyan1*, krishan kumar1, bankim chandra nandy2, richa saxena1. (2017). Design, formulation and in vitro drug release from transdermal patches. International journal of pharmacy and pharmaceutical sciences. Doi:doi: http://dx.doi.org/10.22159/ijpps.2017v9i6.16851

[5]. Rozhan A. Muhammed*, Huner K. Omer. (2020). Formulation and Evaluation of Fast Dissolving Oral Film of Imipramine. Polytechnic Journal. 2020., 182 -188.

[6]. Santosh Jadhav Audumbar Mali Ritesh Suresh Bathe. (2014). Formulation and evaluation of immediate release tablets of Imipramine. International Journal of Biomedical and Advance Research, 188.

[7]. Rajat Pawar*1, Ravi Sharma1, Gajanan Darwhekar 1. (2019). Formulation and Evaluation of Mouth Dissolving Film of Prochlorperazine Maleate. Journal of Drug Delivery and Therapeutics, 110 -115.

[8]. S.G. Sagdinc, Caner Azkeskin, A. Eşme. (2018). Theoretical and spectroscopic studies of a tricyclic antidepressant, imipramine. Journal of Molecular Structure.

[9]. Bhageerathy A, S. M. (2021). formulation and evaluation of fast dissolving film of losartan Potassium. International journal of pharmaceutical science nad research, 237-247.

[10]. Choure, M. S. (2018). Formualtion and evaluation of oral fast dissolving film of cinnarizine. Indo american journal of pharmaceutical science.

[11].S.G. Sagdinc, Caner Azkeskin, A. Eşme. (2018). Theoretical and spectroscopic studies of a tricyclic antidepressant, imipramine. Journal of Molecular Structure.

[12].Pandya K, Patel K, Patel M, Patel N. Fast dissolving films: a novel approach to oral drug delivery. AsianJ PharmSci2013; 3:25-31.

[13].www.researchandmarkets.com/research/ckvqw7/oral\%20thin\%20film. [Last accessed on 20 Jun 2018]

[14]. Thakur N, Bansal M, Sharma N, Yadav G, Khare P. Overview a novel approach of fast dissolving films and their patents. AdvanBiol Res2013; 7:50-8.

[15]. Radhakisan UR, Chavan V, Tribhuvan N. Mouth dissolving film and their patent: an overview. Asian J Biomed PharmSci2012; 3:39-42Vidhi Desai, Nihar Shah (2014),

[16]."Imipramine Use During Pregnancy". Drugs.com. 28 August 2019. Retrieved 7 February 2020.

[17].Heck HA, Buttrill SE Jr, Flynn NW, Dyer RL, Anbar M, Cairns T, Dighe S, Cabana BE (June 1979). "Bioavailability of imipramine tablets relative to a stable isotope-labelled internal standard: increasing the power of bioavailability tests". Journal of Pharmacokinetics and Biopharmaceutics. 7 (3): 233-248

[18].Orsulak PJ (September 1989). "Therapeutic monitoring of antidepressant drugs: guidelines updated". Therapeutic Drug Monitoring. 11 (5): 497-507Nagar P and Y.chauhaniti'(2011), (12),pp:280-289.

[19]. Drug Bank. Available from http://www.drugbank. Ca/drugs/DB00458.

[20]. Ahmed Hassen Elshafeey 1,* and Rania Moataz El-Dahm. (2021). Formulation andDevelopment of Oral Fast-Dissolving Films. MDPI stays neutral.

[21].Reddy G, Ramesh C, Narayana T, Rao K, Rao B. Development of ion-association methods for spectrophotometric assay of Imipramine hydrochloride. Int J Chem Sci 2011; 9:457-64.

[22].Patel, z. (2020). Formulation optimization and evaluation of mouth dissolving film of ramosetron hydrochloride. International journal of current pharmaceutical research.

[23].Patel, V. (2019). Formulation, Development and Evaluation of Fast Dissolving Oral Film of Antipsychotic Drug. journal and drug delivery therapetics.

[24].Pawar, R. (2019). A review on mouth dissolving film. Journal of Drug Delivery and Therapeutics.ElMeshad, A. N. and A. S. El Hagrasy. 2011. Characterization and optimization of orodispersible mosapride film formulations. AAPS PharmSciTech. 12: 1384-1392. 


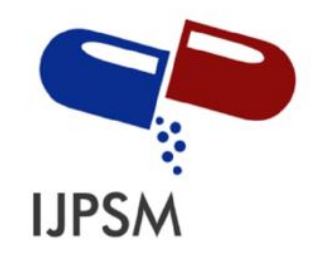

Ravindra Hiwse et al, International Journal of Pharmaceutical Sciences and Medicine (IJPSM), Vol.7 Issue. 1, January- 2022, pg. 59-80

ISSN: 2519-9889

Impact Factor: 5.721

[25].Ghodake, P. P., K. M. Karande, R. A. Osmani, R. R. Bhosale, R. Harkare, B. B. Kale. 2013. Mouth dissolving films: Innovative vehicle for oral drug delivery. Int. J. Pharma Bio Sci. 2: 41-47.

[26]. Buddhadev, s. (2017). Formulation and evaluation of fast dissolving film of etophylline. Http://www.ijapbr.com/ international journal of applied pharmaceutical and biological research, 2017; 2(2):, 48-55.

[27].Jadhav, S. B., A. D. Mali, S. H. Rajeghadage and R. S. Bathe. 2014. Formulation and evaluation of immediate release tablets of Imipramine hydrochloride. Int. J. Biomed. Adv. Res. 5: 559.

[28].Pathan, A. (2016). Formulation and evaluation of fast dissolving oral film of promethazine. Journal of Innovations in Pharmaceuticals and Biological Sciences.

[29].Ketul, P., K. R. Patel, M. R. Patel and N. M. Patel. 2013. Fast dissolving films: A novel approach to oral drug delivery. Int. J. Pharm. 1: 13.

[30]. Bhagawati, A. C. (2015). An Overview on Fast Dissolving Oral Films. Asian Journal of Pharmacy and Technology, 129. 